\title{
Correction to: Relating early hydration, specific surface and flow loss of cement pastes
}

\author{
Sara Mantellato (1) Marta Palacios · Robert J. Flatt
}

Published online: 12 December 2019

(C) The Author(s) 2019

\section{Correction to: Materials and Structures (2019) 52:5 https://doi.org/10.1617/s11527-018-1304-y}

The article "Relating early hydration, specific surface and flow loss of cement pastes", written by "Sara Mantellato, Marta Palacios, Robert J. Flatt", was originally published electronically on the publisher's internet portal (currently SpringerLink) on 4 January 2019 without open access.

The copyright of the article changed in December 2019 to (C) The Author(s) 2019, and the article is forthwith distributed under the terms of the Creative Commons Attribution 4.0 International License (http://creativecommons.org/licenses/by/4.0/), which permits use, duplication, adaptation, distribution and reproduction in any medium or format, as long as you give appropriate credit to the original author(s) and the source, provide a link to the Creative Commons license and indicate if changes were made.

Open Access This article is distributed under the terms of the Creative Commons Attribution 4.0 International License (http:// creativecommons.org/licenses/by/4.0/), which permits unrestricted use, distribution, and reproduction in any medium, provided you give appropriate credit to the original author(s) and the source, provide a link to the Creative Commons license, and indicate if changes were made.

Publisher's Note Springer Nature remains neutral with regard to jurisdictional claims in published maps and institutional affiliations.

The original article can be found online at https:// doi.org/10.1617/s11527-018-1304-y.

S. Mantellato $(\bowtie) \cdot$ M. Palacios · R. J. Flatt Institute for Building Materials, ETH Zürich, StefanoFranscini-Platz 3, 8093 Zurich, Switzerland e-mail: sara.mantellato@ifb.baug.ethz.ch

R. J. Flatt

e-mail: flattr@ethz.ch

M. Palacios

Eduardo Torroja Institute for Construction Science, Serrano Galvache 4, 28033 Madrid, Spain 